\title{
スケトウタラ内臟油の高級アルコール*
}

\author{
内 藤 幸 次・橋 本 芳 郎 \\ (1960 年 6 月 10 日受理)
}

\section{HIGHER ALCOHOLS IN POLLACK VISCERA OIL}

\author{
Koji NaIto and Yoshiro Hashimoto**
}

Hexadecanol, together with the less amount of tetradecanol, was found to occupy the greater part of fatty alcohols in pollack viscera oil. Two monoethenoid alcohols were isolated as minor components, and identified as $\Delta^{10}$-eicosenol and $\Delta^{11}$-docosenol, respectively. This may be the first finding of the occurrence of $\Delta^{10}$-eicosenol in marine animal oils.

Unsaponifiable matters $(364 \mathrm{~g})$ obtained from commercial pollack viscera oil $(29.7 \mathrm{~kg})$ were dissolved in about one litre of acetone and left stand overnight to remove the most part of sterols. The remaining liquid unsaponifiables $(198 \mathrm{~g}$ ) were acetylated, and divided into five fractions by distillation under the reduced pressure, as shown in Table 1 . Alcohols in each fraction were purified by alumina column chromatography and fractional crystallization from acetone at low temperature.

From the fractions I and II, tetradecanol (m.p. and mixed m.p. $37.8^{\circ} \mathrm{C}$ ) and hexadecanol (m.p. and mixed m.p. $49.5^{\circ} \mathrm{C}$ ) were obtained. They were also derived to phenylurethane or $\alpha$-naphthylurethane for identification.

Colorless plates (m.p. $24.5 \sim 25.0^{\circ} \mathrm{C}$ ) from the fraction III, were identified as $\Delta^{10}$-eisocenol, by obtaining eicosanol (m.p. $65 \sim 66^{\circ} \mathrm{C}$ ) on the hydrogenation in the presence of palladium black and two decomposition products, capric and sebacic acids, on the oxidation with potassium permanganate and chromic acid. By the similar method, the monoethenoid alcohol from the fraction IV, was identified as $\Delta^{11}$-docosenol (m.p. $31.5^{\circ} \mathrm{C}$ ), which gave docosanol (m.p. $70 \sim$ $70.5^{\circ} \mathrm{C}$ ) on hydrogenation and both undecanoic and undecadioic acids on oxidation.

From the fractions III, IV and V, the considerable amounts of cholesterol and cholesta3,5-diene, a pyrolysis product of cholesteryl acetate, were isolated.

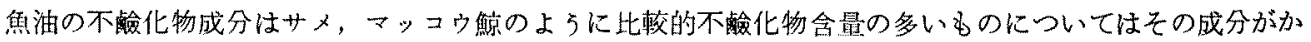

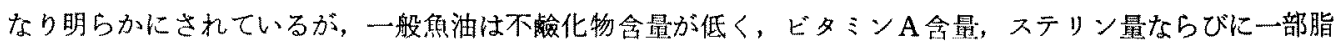
肪族炭化水素の存在が判つている程度で，その主成分と考えられる高級アルコールについてはあまり研究が 招こなわれていない。最近, 小森等”はウケグチタラ肝油の高級アルコール成分を検索し, 主成分として $\Delta^{11}$-docosenol の存在を認め， $A^{11}$-eicosenol, oleylalcohol 等の不飽和脂肪アルコールを分離している。

著者等はビタミンA源として座業上重要なスケトゥタラ内臓油の不羷化物成分のうち特に高級フルコール について検索を試みたのでここに報告する。

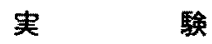

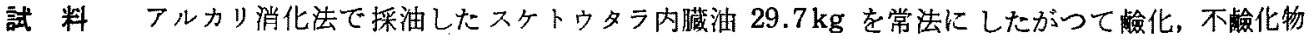
$364 \mathrm{~g}$ を壳た。これを約 $1000 \mathrm{~m} l$ のアセトンに溶解， $0^{\circ} \mathrm{C}$ に一昼夜放㯰，析出するステリンを沪別し，液 状油 $298 \mathrm{~g}$ をえた。これを 2 倍量の無水酰酸と加熱してアセチル化，酢化合物 $295 \mathrm{~g}$ を完，全がラス製の塔
}

* 本研究の大要は 1960 年 4 月，日本䶘学大会水産部会に拈いて発表した。

** 軍京大学费学部 (Lab. Fish. Chem., Fac. Agr., Univ. of Tokyo). 
高 $60 \mathrm{~cm}$ の電热充垻式精留落をるちい,ーリックスを充埧物として $3 \mathrm{mmHg}$ の減圧下に分留を呿こなつ た。分留結果は Table 1 のごとくである。

Table 1. Fractional distillation of acetates of unsaponifiables from pollack viscera oil.

\begin{tabular}{c|c|c|c|c}
\hline \hline Fractions & b.p. $\left({ }^{\circ} \mathrm{C}\right)$ & $\begin{array}{c}\text { Yield Wt. } \\
(\mathrm{g})\end{array}$ & Sapon. value & Alcohols identified \\
\cline { 2 - 5 } & $89 \sim 150$ & 51.0 & 163.7 & Tetradecanol, Hexadecanol \\
I & $150 \sim 170$ & 41.5 & 154.1 & " \\
II & $170 \sim 200$ & 24.0 & 122.0 & Cholesterol, $4^{10}$-Eicosenol \\
III & $200 \sim 220$ & 38.0 & 101.9 & Cholesterol, $4^{11}$-Docosenol \\
IV & $220 \sim 233$ & 43.0 & 50.8 & Cholesterol \\
V & & 67.0 & & \\
Residue & & & \\
\hline
\end{tabular}

\section{Tetradecanol (Myristylalcohol) むよび Hexadecanol (Cetylalcohol) の分離, 確認}

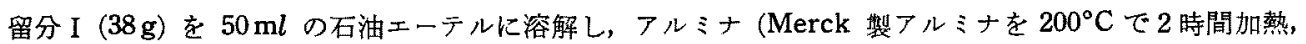
活性化したもの，以下同様に処理）を吸着肪としたクロマトグラフ $(3 \times 30 \mathrm{~cm})$ を呿こない，約 $300 \mathrm{ml} の$ 石油エーテルを展開㓮としてもちい,アルミナに吸着されない画分 $33 \mathrm{~g}$ をえた。高級アルコ一ルの酢化合 物はここに含まれる。石油エーテル溶出区分を常法にしたがつて醶化，不酹化物を 3 倍量のアセ卜ンに溶解 し $0^{\circ} \mathrm{C}$ に一昼夜放置すると多量の板状結晶が析出した。アセトンょり数回再結晶を繰返し, 無色の絹系状光 沢を有する板状結晶 $9.3 \mathrm{~g}$ をえた。 m.p. $49.5^{\circ} \mathrm{C}$ (mixed m.p. $49.5^{\circ} \mathrm{C}$ ), 分子量 (Rast) 240，その酢酸溶 液に臭素永酢酸溶液を 1 滴加えても裉色しないことから本結晶は hexadecanol $\left(\mathrm{C}_{16} \mathrm{H}_{33} \mathrm{OH}\right)$ と判定した。 さらに確認のため $\alpha$-naphthylurethane となし, m.p. $82^{\circ} \mathrm{C}$ (mixed m.p. $82^{\circ} \mathrm{C}$ ) の板状結晶をえ, これよ り hexadecanol なることを確認した。

hexadecanol を除いた母夜より溶剤を留去後残留物をベンゼンに溶解，再びアルミナクロマトグラフを 特こなつて順次展開夜の溶出力を高めベンゼソ・エーテル混液（2：1）で溶出する部分を採り，フ七トンに 溶解して $-5 \sim-10^{\circ} \mathrm{C}$ に冷却すると白い沈筑物が析出した。すみやかに沪別し，アセトンより低温で再結 晶を繰返して $2.7 \mathrm{~g}$ の無色板状結晶をえた。 m.p. $37.8^{\circ} \mathrm{C}$ (mixed m.p. $37.8^{\circ} \mathrm{C}$ ), その酶酸溶液に臭素氷酭 酸溶液 1 滴を加えてる祖色せず， tetradecanol と考完られるので，その一部を phenylurethane となし， m.p. $70.7^{\circ} \mathrm{C}$ の結晶をえた。これより本結晶が tetradecanol なることを確認した。

留分 II に批いても全く同様の方法で留分 $33 \mathrm{~g} よ り$ hexadecanol $10.2 \mathrm{~g}$, tetradecanol $1.7 \mathrm{~g}$ をえた。 なお hexadecanol の再結晶の際第 1 回目に兄られる母没を蕽縮後 $-40^{\circ} \mathrm{C}$ に冷却すると白い析出物がえら れ、フセトン上り数回再結すると小さな板状結晶となり m.p. $41.0^{\circ} \mathrm{C}$ となつたが, 再結後る融点上乐せず, また臭素氷酶酸液を裉色しないことから hexadecanol と tetradecanol の混合物であるらと思われる。

\section{II. $A^{10}$-Eicosenol の分離, 確認}

留分 II (18g) 石油エーテルに溶解，フルミナクロマトグラフを枋こなつて石油ニーテル溶出区分 $12.2 \mathrm{~g}$ を光た。前実験と同様に不喃化物を党，アセトンに溶解して $-5^{\circ} \mathrm{C}$ に数日間放置し，析出した固形分を母

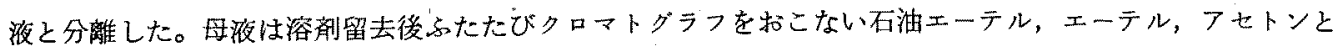
順次溶出力の強い溶剤をもちい, 石油エーテル溶出区分 $3.4 \mathrm{~g}$ (アセトン,ェタノールに難溶, $-50^{\circ} \mathrm{C}$ に泠却 するす固化せず脂肪族炭化水素と思われる)，アセトン溶出区分 $1.7 \mathrm{~g}$ (アセトンより数回再結, m.p. $148^{\circ} \mathrm{C}$, cholesterol と思われる)をえた。

固形分 (3.8g) は石油エーテルに溶解し，ふたたびクロマトグラフを括こなつた。石油エーテル，エーテ ル,メタノールの順に溶出を括こない, 石油エーテル溶出区分 $0.9 \mathrm{~g}$ (アセトンより数回再結, 収量 $0.7 \mathrm{~g}$, 柱状結晶， m.p. $78.8^{\circ} \mathrm{C}$, cholesta-3,5-diene で cholesteryl acetate の熱分解によつて生成したもの。こ 
の点については别に報告する)，メタノール溶出区分 $0.5 \mathrm{~g}$ (メタノールより再結, 収量 $0.3 \mathrm{~g}$, 無色板状結 晶, m.p. $147.5^{\circ} \mathrm{C}$, cholesterol と思われる) をえだが䧟半量が第 2 目の溶剤, エーテルで溶出された。 エーテルを留去後少量のアセトンに溶解して $-20^{\circ} \mathrm{C}$ に泠却, 析出したロゥ状物質をすみやかに沪別し, 数 回稀アセトンより再結を繰返し，無色の結晶 $1.4 \mathrm{~g}, \mathrm{~m} . \mathrm{p} .25^{\circ} \mathrm{C}$ をえた。

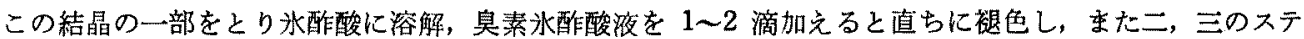
リン反応は陰性で，不飽和直鎖アルコールと考光，精製の目的でふたたびアルミナクロマトグラフを放こな つた。ベンゼンに溶解し，徐々にェーテル濃度を増したところぺンゼン・エーテル混液（7: 3) で結晶の大 部分が脱着された。溶㓣を留去し， m.p. 24.5 25.0 $0^{\circ} \mathrm{C}$ 小さな板状結晶 $0.9 \mathrm{~g}$ をえた。この結晶の元素 分析の結果は C: $80.90, \mathrm{H}: 13.42 \%$ て eicosenol $\left(\mathrm{C}_{20} \mathrm{H}_{40} \mathrm{O}\right)$ の計算値 C: $81.01, \mathrm{H}: 13.59 \%$ とく一 致する。さらにパラジュウム黑を触媒とし，無水アルコールを溶凧として水素添加を括こない，m.p. 65〜

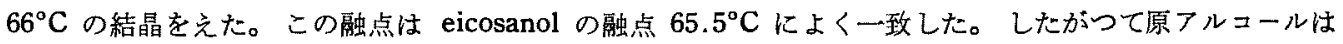
eicosenol と判定した。

つぎにこの eicosenol を無水酢酸と加熱してふたたび acetate となし，10倍量のアセトンに溶解，試料 の 6 倍量の過マンガン酸カリ粉末を 1.5 時間にわたつて添加, 酸化分解を完結させるためにさらに 16 時間 湯浴上で加熱した。アセトンを留去後生成した二酸化マンガンを亜硫酸水で溶解し，分解物をエーテル抽出 してェーテル層に集め,さらに炭酸ソーダ抽出を抗こなつて未分解物と分離した。炭酸ソ一ダ抽出液には脂 肪酸とオキシ酸 acetate が含まれているのでオキシ酸 acetate をオキシ酸とするために苛性かりを使用し て䲓化，簽化滩に塩酸を加えて酸性となし，石油エーテル抽出をおこなつた。この際石油エーテルに不溶の オキシ酸は石油エーテル層と水層の界面に懸濁するので汇過によつて脂肪酸と分離できた2。 オキシ酸はエ ーテルに溶解して集め, 石油エーテルよりは脂肪酸をえて，つぎのごとく検索した。

石油エーテルを留去して交た脂肪酸区分は白色ワセリン上5の固体で少量のため分留しえなかつたが， m.p. 29.0 29. $3^{\circ} \mathrm{C}$, 中和価 323.1 で capric acid $の$ m.p. $31.5^{\circ} \mathrm{C}$, 中和価 325.7 に非常に近いが, 融点 が多少低いので酸アミドとした。塩化チオニールで脂肪酸塩化物となし，これをアンモニア水と反心させ脂 肪酸アミドとしだ”。稀アルコールより数回再結し, m.p. $96.5 \sim 97.0^{\circ} \mathrm{C}$ (capric acid のアミド m.p. $98^{\circ} \mathrm{C}$ ) の白い葉状結晶孛壳た。

以上の性状より脂肪酸は capric acid $\mathrm{CH}_{3}\left(\mathrm{CH}_{2}\right)_{8} \mathrm{COOH}$ と判定した。

エーテルを留去してえたオキシ酸を10 倍量の水酢酸に溶解, 算水クロム酸を加えて沸騰浴上で 1 時間加 温，二塩基性酸とした”。反応生成物をエーテルに溶解後，多量の水を加えて水洗し，エーテルを留去した 残椬を数回熱水より再結し，無色葉状結晶をえた。m.p. 129〜130 $\mathrm{C}$ ，中和洒 539.3 でこの二塩基性酸は sebacic acid (HOOC. $\left(\mathrm{CH}_{2}\right)_{8} \cdot \mathrm{COOH}$, m.p. $133^{\circ} \mathrm{C}$, 中和価 554.8 ) と判定した。

以上の結果よりこの eicosenol の構造は $d^{10: 11-e i c o s e n o l ~} \mathrm{CH}_{3} \cdot\left(\mathrm{CH}_{2}\right)_{8} \mathrm{CH}: \mathrm{CH}\left(\mathrm{CH}_{2}\right)_{8} \mathrm{CH}_{2} \mathrm{OH}$ であるこ とを確認した。

$\Delta^{10}$-eicosenol はこれまで人間の毛髪の脂肪にその存在が明らかにされている゙) のみで水産油脂での存在 は始めてである。

\section{III. $d^{11}$-Docosenol の分離, 確認}

留分 IV $(22.5 \mathrm{~g})$ を石油エーテルに溶解，アルミナクロマトグランをこなつて石油エーテル溶出区分 $20.8 \mathrm{~g}$ をえた。これを畧化後ふたたびクロマドグラフを执こなつて石油エーテル溶出区分とメタノール溶出 区分に分けた。

石油エーテル容出区分はアセトソに溶解し， $-5^{\circ} \mathrm{C} に 一$ 昼夜放置すると多量の柱状結晶が析出し，アセトン より数回再結後, 無色の柱状結晶 $5.4 \mathrm{~g}$ をえた。この結晶は m.p. $\left.77^{\circ} \mathrm{C},[\alpha]_{\mathrm{D}}^{16}=-118^{\circ} \mathrm{CHCl}_{3}\right), \lambda_{\max }=$ $235 \mathrm{~m} \mu$ (EtOH), LIEBERMANN-BURCHARD 反応陽性で cholesta-3,5-diene である。

メタノール溶出区分 $7.8 \mathrm{~g}$ を少量のアセトンに溶解し, 䄪 $5^{\circ} \mathrm{C}$ に一昼夜放置すると結晶が析出した。メ タノールより数回再結を繰返し無色板状結晶 $1.7 \mathrm{~g}$ をえた。 m.p. $148 \sim 148.5^{\circ} \mathrm{C},[\alpha]_{\mathrm{D}}^{1 \mathrm{~K}}=-34.5^{\circ}, ア ル コ$ 一ル溶液はヂギトニンと沈澱反応を示し，LIEBERMANN-BURCHARD 反応陽性であることから cholesterol と判定した。この cholesterol を河別した母液より溶凮を留去し，石油エーテルに溶解，ふたたびアルミナ

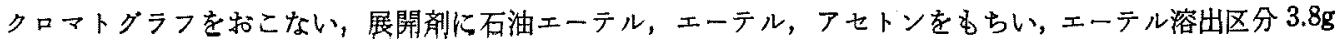
をえた。 
これをアセトンに溶解し，ドライフイスで $-20^{\circ} \mathrm{C}$ に保ち，析出する結晶を素早く汇別し， m.p. $31.5^{\circ} \mathrm{C}$ の無色結晶 $1.8 \mathrm{~g}$ をえた。この結晶は LIEBERMANN-BURCHARD 反応が陰性で一部を氷酢酸に溶解し，臭

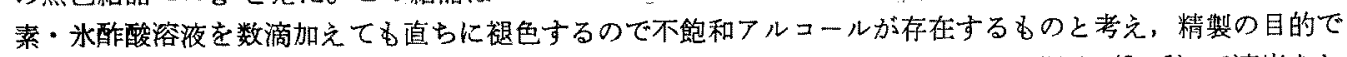
さらにアルミナクロマトグラフを抗こなつた。結晶の大部分はベンゼン・エーテル混液 $(2: 1)$ で溶出され m.p. $30 \sim 31.5^{\circ} \mathrm{C}$ の無色板状結晶 $1.4 \mathrm{~g}$ を元た。元素分析結果は C: $81.05, \mathrm{H}: 13.65 \%$ で docosenol $\left(\mathrm{C}_{20} \mathrm{H}_{44} \mathrm{O}\right)$ の計算値 C: $81.50, \mathrm{H}: 13.66 \%$ とよく一致した。バラジゥム黑を触媒として水素添加を行つた 結果, m.p. 70 70.5 $5^{\circ} \mathrm{C}$ を示した。この融点は docosanol の m.p. $70.3 \sim 70.8^{\circ} \mathrm{C}$ によく一致した。すな わち原フルコールは融点, 前記の性状より docosenol であることを確認した。

つぎに前述の eicosenol の構造決定の場合と全く同棁に acetate を過マソガン酸カりで酸化分解し，脂 肪酸とオキシ酸となし，オキシ酸をクロム酸酸化で二塩基性酸とした。酸化分解してえた脂肪酸はやや褐色 を帯びていたので減圧分留によりその主留分と思われる $120 \sim 141^{\circ} \mathrm{C} / 2 \sim 3 \mathrm{mmHg}$ の留分をえた。 m. p. $27.0 \sim 27.5^{\circ} \mathrm{C}$, 中和価 301.4 でこの脂肪酸より光たアミドは m.p. $97.5^{\circ} \mathrm{C}$ を示し, これらの特数より本脂

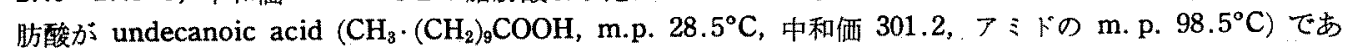
ることを確認した。

一方クロム酸酸化でえた二塩基性酸は熱水上り数回再結したところ無色の小さな板状結晶を兄た。m.p. $113^{\circ} \mathrm{C}$, 中和価 508.0 で, この特数よりこの二塩基性酸は undecanedioic acid (HOOC. $\left(\mathrm{CH}_{2}\right)_{8} \cdot \mathrm{COOH}$, m.p. $113.2^{\circ} \mathrm{C}$, 中和価 518.8 ) であることを確認した。

以上の実験結果より docosenol の灀造は 41: 12-docosenol $\mathrm{CH}_{3}\left(\mathrm{CH}_{2}\right)_{9} \mathrm{CH}: \mathrm{CH}\left(\mathrm{CH}_{2}\right)_{9} \mathrm{CH}_{2} \mathrm{OH}$ であるこ とが明らかとなつた。

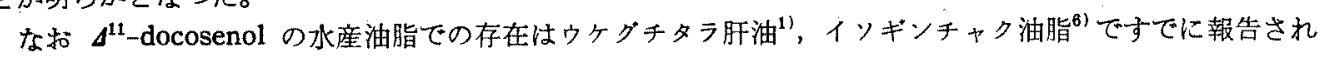
ている。

留分 V は留分 IV と同様に分画を括こなつたが，その主成分として cholesta-3,5-diene と cholesterol の結晶をえたのみで，脂肪族高級フルコールの存在は認めなかつた。

控

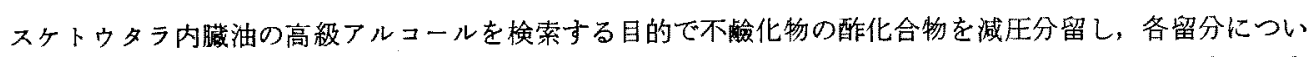
て検討を怙こなつた。低沸点留分よりはアルミナクロマトグラフ，低温結晶化法等を試みて tetradecanol， および hexadecanol を分離しそそれぞれ urethane を克て確認した。高沸点留分よりは同様にクロマトグ ラフ，低温結晶化等の操作により水産油脂ではこれまでに報告を見ない $\Delta^{10}$-eicosenol, ならびにウケグチ タラ,イソギンチャク油脂にその存在が明らかにされている $\Delta^{11}$-docosenol を分離した。これらの monoet. henoid alcohol は水素添加, 過マソガン酸かリによる酸化分解, さらにクロム酸酸化法等によつて棈造を 決定した。

スダトゥタラ内臟油の高級アルコールはその主成分が hexadecanol で， tetradecanol が，これにつぎ， eicosenol, docosenol の含量は極めて少いようである。な拉アルコールの存在は本寒験では認められなか つた。

終りに臨み不鲙化物の分取に協力を睗わつた日本水産研觉所ならびに当研究室德田節子氏, 高級アルコー 儿の分離, 確認に協力された当研究室堤 淳三君および元素分析を担当された東大慦芸化学分析室の方々に 厚く感謝の意を表する。本実験の一部は文部省科学研究費によつて抗こなわれたるのである。

\section{文献}

1) 小森三郎・阿河利男：日化, 75, 1051 (1954).

2) 喜多源逸編：油脂化学及び試験法, p. 341, 至文堂, (1958).

3) 浅野三千三: 薬誌, No. 480, 97 (1922).

4) 外山修之: 日化, 59, 810 (1938).

5) HougEN, F. H.: Biochem. J., 59, 302 (1955).

6) Bergmann, W., Creighton, S, M. and Stockes, W. M.; J. Org. Chem., 21, 721 (1956). 